\title{
BLACK SPACE
}


THIS PAGE INTENTIONALLY LEFT BLANK 


\section{BLACK SPACE}

Imagining Race in Science Fiction Film

ADILIFU NAMA

UNIVERSITY OF TEXAS PRESS, AUSTIN 
COPYRIGHT (C) 2008 BY THE UNIVERSITY OF TEXAS PRESS

All rights reserved

Printed in the United States of America

First edition, 2008

Requests for permission to reproduce material from this work should be sent to:

Permissions

University of Texas Press

P.O. Box 7819

Austin, TX 78713-78I9

www.utexas.edu/utpress/about/bpermission.html

@ The paper used in this book meets the minimum requirements of ANSI/NISO Z39.48-I992 (RI997) (Permanence of Paper).

Library of Congress Cataloging-in-Publication Data

Nama, Adilifu, I969-

Black space : imagining race in science fiction film / Adilifu Nama. - Ist ed. p. cm.

Includes bibliographical references and index.

ISBN 978-0-292-7I697-I (cloth : alk. paper) -

ISBN 978-0-292-7I745-9 (pbk. : alk. paper)

I. Science fiction films-History and criticism. 2. Blacks in motion pictures.

3. African Americans in motion pictures. I. Title.

PNI995.9.S26N36 2008

79I. $43^{\prime} 6 \mathrm{I} 5-\mathrm{dc} 22$

2007033323 
FOR NIA, NIZAM, AND TAMU 
THIS PAGE INTENTIONALLY LEFT BLANK 